\title{
MGMT: A Personal Perspective
}

\author{
Sankar Mitra \\ Department of Biochemistry and Molecular Biology, University of Texas Medical Branch, Galveston, \\ TX 77555
}

The discovery of $O^{6}$-methylguanine-DNA methyltransferase (MGMT), first in E. coli, and subsequently in mammals, yeast and other eukaryotes, underscores the importance of the endogenous and induced formation of $O^{6}$-alkylguanine $\left(O^{6}\right.$-alkylG) as well as the need for its repair to prevent mutations due to this mutagenic base adduct. Parallel and independent studies on the dual functions of alkylating agents that generate $\mathrm{O}^{6}$-alkylG (and other alkylated base adducts), in the induction of carcinogenesis, as well as in the chemotherapy of cancer, led to an explosive interest in the study of $\mathrm{O}^{6}$-alkylG, its formation and its repair, in the 80s. Studies on DNA methylation damage repair received a new boost with the more recent exciting discovery of a novel mechanism that repairs 1-methylA and 3-methylC both in single-stranded DNA and RNA by E. coli Alk B and its mammalian homologs ABH2 and ABH3. These enzymes are dioxygenases that act via oxidative demethylation (1-3) and this is reviewed elsewhere in this volume. This short review summarizes from my personal perspective, the early history of the discovery of $\mathrm{O}^{6}$-alkylG repair in bacteria and mammals and its clinical implications.

\begin{abstract}
Alkylating agents directly react with cellular macromolecules as electrophiles or generate electrophilic species after metabolic activation (reviewed in 4). These attack nucleophilic targets including DNA bases and phosphates, via $\mathrm{S}_{\mathrm{N}} 1$ or $\mathrm{S}_{\mathrm{N}} 2$ mechanisms (reviewed in 5). Lawley and Brooks pioneered studies of alkylating agents in the etiology of carcinogenesis more than forty years ago (6). Early studies by Lawley, Brooks, Magee, Singer and others demonstrated the formation of alkylated bases in RNA and DNA after reaction with alkylating carcinogens (6-8). The alkylation sites in DNA bases are now known to be the N1, N3, N7 atoms in purines, $\mathrm{N} 3$ and $O^{2}$ atoms in pyrimidines and the $O^{4}$ and $O^{6}$ atoms in $\mathrm{T}$ and $\mathrm{G}$, respectively. Alkylation at $\mathrm{N} 3$ and $\mathrm{N} 7$ in $\mathrm{G}$ and A, and $O^{2}$ in C, destabilizes the glycosyl bond of the base and its spontaneous release leads to abasic (AP) sites. For a long time 7-alkylG was believed to be the key carcinogenic lesion (reviewed in 5). $O^{6}$-alkylation of $\mathrm{G}$ was not considered to be of critical significance because of its low abundance until Loveless proposed in 1969 in a seminal paper that $O^{6}$-alkylG should be mutagenic because of its mispairing potential with T (9). Even though the etiologic role of mutations in carcinogenesis was not established until much later, that mutations could lead to cancer was generally accepted at that time. Then Goth and Rajewsky (10) showed that $O^{6}$-ethylG but not 7-ethylG persists in the brain DNA of rats treated with N-ethyl-N-nitrosourea (ENU) which was consistent with the organotropism of $\mathrm{N}$-nitrosamides in inducing CNS tumors in rodents (10). Kleihues and Margison independently showed that accumulation of $O^{6}$-methylG could be correlated with glial tumors induced by N-methyl-N-nitrosourea (11). These studies of Rajewsky and Kleihues and of Magee et al, are considered to be classic and led to increased interest in the mutagenic and carcinogenic properties of $O^{6}$-alkylG. Early studies on in vitro replication indicating that
\end{abstract}

\footnotetext{
Publisher's Disclaimer: This is a PDF file of an unedited manuscript that has been accepted for publication. As a service to our customers we are providing this early version of the manuscript. The manuscript will undergo copyediting, typesetting, and review of the resulting proof before it is published in its final citable form. Please note that during the production process errors may be discovered which could affect the content, and all legal disclaimers that apply to the journal pertain.
} 
$O^{6}$-methylguanine $\left(\mathrm{m}^{6} \mathrm{G}\right)$ in a DNA template tends to incorporate $\mathrm{T}$ rather than $\mathrm{C}$ were consistent with Loveless's hypothesis about ambiguous base pairing of $O^{6}$-alkylG (12).

\section{Evidence of mutagenic nature of $0^{6}$-methyIG}

One problem of studying the effect of $\mathrm{O}^{6}$-alkylG in DNA is that alkylating agents alkylate multiple sites in bases as well as phosphate residues, among which $\mathrm{O}^{6}$-alkylG is a relatively minor base adduct. This makes it rather difficult to establish a causal linkage between a biological end point and a specific alkyl lesion, e.g., $\mathrm{O}^{6}$-alkylG. We therefore decided to study $\mathrm{m}^{6} \mathrm{G}$ as a unique base adduct in DNA. We generated $\mathrm{O}^{6}$-methyldGTP ( $\mathrm{m}^{6} \mathrm{dGTP}$ ) by chemical synthesis using established protocols, and were also able to label the $\mathrm{C}-8$ position of $\mathrm{G}$ with $\left[{ }^{3} \mathrm{H}\right]$ by starting with 8-bromo- $O^{6}$-methyldGTP and then reducing it with $\left[{ }^{3} \mathrm{H}_{2}\right](13)$. We collaborated with Warren Masker to examine the effect of incorporation of $\mathrm{m}^{6} \mathrm{dGMP}$ in an in vitro $\mathrm{T} 7$ phage DNA replication assay (14). We showed that incorporation of $\mathrm{m}^{6} \mathrm{dGMP}$ into replicated DNA, which was subsequently packaged in vitro for infectivity assays, significantly increased the reversion frequency of an amber mutation. This could be easily explained if incorporation of $\mathrm{m}^{6} \mathrm{G}$ opposite $\mathrm{T}$ induced a transition mutation for $\mathrm{AT} \rightarrow \mathrm{GC}$, as in the amber codon of mutation of $\mathrm{T}$ to $\mathrm{C}$ in TAG during replication (14). This was the first biological evidence of $\mathrm{m}^{6} \mathrm{G}$ mispairing with T. Subsequently, John Essigman's lab, in an elegant study involving site-specific incorporation of $\mathrm{m}^{6} \mathrm{G}$ into a plasmid, showed that this base was mutated to A upon plasmid replication (15).

Liza Snow, a Ph.D. student in our laboratory, then synthesized $\mathrm{m}^{6} \mathrm{G}$-containing oligodeoxynucleotides using terminal deoxynucleotidyl transferase which resulted in random incorporation of $\mathrm{m}^{6} \mathrm{G}$ in polydeoxy $\left(\mathrm{C}, \mathrm{G}, \mathrm{m}^{6} \mathrm{G}\right)$. She used various prokaryotic DNA polymerases to show that both $\mathrm{T}$ and $\mathrm{C}$ were incorporated during replication of the $\mathrm{m}^{6} \mathrm{G}$ containing template but not of a similar template that did not contain $\mathrm{m}^{6} \mathrm{G}$ (16). This provided strong evidence for the ability of $\mathrm{m}^{6} \mathrm{G}$ to pair with $\mathrm{T}$. She also determined the kinetic parameters of DNA synthesis to conclude that $\mathrm{m}^{6} \mathrm{G}$ inhibits DNA polymerase activity. Nevertheless, all DNA polymerases incorporated $\mathrm{T}$ when $\mathrm{m}^{6} \mathrm{G}$ was present in the template. Her complementary studies examining incorporation of $\mathrm{dm}^{6} \mathrm{GMP}$ opposite $\mathrm{T}$ in DNA were consistent with this conclusion (17). More recently, studies were carried out with well-defined templates with sitespecific location of $\mathrm{m}^{6} \mathrm{G}$ and replication with purified eukaryotic DNA polymerases (18). These studies confirmed that DNA polymerases pause at the $\mathrm{m}^{6} \mathrm{G}$ residue before incorporation of $\mathrm{C}$ or $\mathrm{T}$. Thus the DNA polymerases may have difficulty in aligning the complementary $\mathrm{C}$ or $\mathrm{T}$ opposite $\mathrm{m}^{6} \mathrm{G}$ prior to their incorporation. Furthermore, the base pairing of $\mathrm{m}^{6} \mathrm{G}$ with $\mathrm{C}$ or T using $2 \mathrm{H}$ - bonds rather than $3 \mathrm{H}$-bonds as present in a $\mathrm{G} \cdot \mathrm{C}$ pair is weak. Our results showing increased turnover of $\mathrm{C}$ or $\mathrm{T}$ during replication of the $\mathrm{m}^{6} \mathrm{G}$-containing template supports this conclusion. Subsequent NMR spectroscopy and X-ray crystallography studies of $m^{6} \mathrm{G}$-containing oligonucleotides provided direct evidence for the $\mathrm{m}^{6} \mathrm{G} \bullet \mathrm{T}$ pair $(19,20)$.

\section{Adaptive response of E. coli to MNNG}

While investigations on the contribution of $\mathrm{O}^{6}$-alkylG to mutagenesis and carcinogenesis were continuing at a slow pace, a paradigm-shifting discovery established the concept of adaptive response in $E$. coli to alkylating agents which opened up a completely new approach to study repair of this mutagenic base lesion. Leona Samson in her Ph.D. dissertation project in John Cairns' laboratory was investigating the mechanism and kinetics of mutagenesis in E. coli by $N$-methyl- $N$ '-nitro- $N$-nitrosoguanidine (MNNG), a classical agent used for generating $E$. coli mutants (21). MNNG is activated by thiols to generate methyldiazonium ions that alkylate DNA bases and phosphates via the $\mathrm{S}_{\mathrm{N}} 1$ mechanism. Samson and Cairns observed that $E$. coli pretreated with submutagenic dose of MNNG became resistant to both mutagenesis and killing when challenged with a much higher dose of MNNG, and they named this phenomenon, 
"adaptive response" (21). It should be noted that the mutagens are invariably cytotoxic and cytotoxicity and mutagenesis occur simultaneously. A similar phenomenon, (named the Weigel effect, after the discoverer), showing enhanced survival of UV-pretreated E. coli to a challenge dose of UV, was established many years earlier, and was subsequently linked to the SOS response (reviewed in 22). In this case, however, UV-pretreated E. coli developed resistance to UV, but simultaneously showed enhanced mutagenesis. It later became evident that UV (and as well as other genotoxic agents) activate the SOS response by inactivating the LexA repressor. The SOS regulon consists of multiple operons which encode not only repair proteins for UV damage but also specialized DNA polymerases for lesion by-pass synthesis, resulting in increased mutation frequency (22).

The Cairns Laboratory showed that the adaptive response is distinct from the SOS response in that MNNG pretreatment reduced both the toxic and the mutational effects of alkylating agents but not those of other genotoxic agents such as UV light (23). It is a testimony to the remarkable insight and ingenuity of John Cairns and his associates that they unraveled the molecular basis of the adaptive response. Subsequent studies showed that, by analogy with the SOS response triggered by UV light, the adaptive response corresponds to activation of the ada gene. The Ada polypeptide regulated several operons including that of $a d a$ itself, as in the case of the SOS regulon $(24,25)$. However, unlike in the case of the SOS response, where regulation is negatively controlled by the LexA repressor, the Ada polypeptide acts as an activator of the genes involved in adaptive response which include $a d a, a l k A, a l k B$ and aid $B$, all of which were expected to be involved in methylated DNA repair or tolerance. However, the mechanism of activation is slightly different for each gene $(26,27)$.

The Cairns group identified the functions of Ada, and established that Ada itself is responsible for repairing the principal mutagenic lesions induced by alkylating agents. Lindahl's group identified $\mathrm{O}^{4}$-methylthymine among these as an Ada substrate. More in-depth studies on the mechanism of Ada regulation were subsequently carried out by Lindahl, Sekiguchi and their colleagues. Ada activates the alkA gene; AlkA excises $\mathrm{O}^{2}$-methyl $\mathrm{C}$ and $\mathrm{O}^{2}$-methyl $\mathrm{T}$ in the first step of their repair via the base excision repair (BER) pathway (reviewed in 28). AlkB, as already mentioned, restores $\mathrm{A}$ and $\mathrm{C}$ from 1-methyl $\mathrm{A}$ and 3-methyl $\mathrm{C}$ respectively via oxidative demethylation (1-3). Finally, Aid B's enzymatic role in methylation repair is still unclear (29). Cairns and his associates predicted from their in vivo data that (a) Ada acts stoichiometrically in the repair of mutagenic alkylated bases, and (b) AlkA acts catalytically (23). Subsequent studies confirmed these remarkable predictions.

\section{Discovery of the MGMT reaction mechanism}

The biochemical mechanism of action of Ada in vitro was independently discovered by us and by Lindahl and Olsson $(13,30)$ using two different DNA substrates that provided complementary information (Fig. 1). In our efforts to elucidate the mutagenic mechanism of $\mathrm{m}^{6} \mathrm{G}$, we incorporated $\mathrm{d}\left[{ }^{3} \mathrm{H}\right] \mathrm{m}^{6} \mathrm{GMP}$ into a synthetic oligonucleotide, polydeoxy $(\mathrm{C}, \mathrm{G}$, or $\mathrm{m}^{6} \mathrm{G}$ ), as already described. It should be noted that our studies predate the era of chemical synthesis of oligodeoxynucleotides using phosphoramidite or phosphotriester chemistry. Our synthesis of polydeoxy $\left(\mathrm{C}, \mathrm{G}, \mathrm{m}^{6} \mathrm{G}\right)$ was based on the rationale that with nearly equimolar amounts of $\mathrm{C}$, and $\mathrm{G}$ together with $\mathrm{m}^{6} \mathrm{G}$, these polymers would contain a significant amount of duplex structure including the $\mathrm{m}^{6} \mathrm{G} \cdot \mathrm{C}$ pairs that would be present in methylated DNA.

We incubated the DNA substrate with extracts of $E$. coli pretreated with MNNG for adaptation. After incubation, the radioactivity remained in DNA which we then isolated by phenol extraction and alcohol precipitation. After hydrolysis of DNA with DNase I, snake venom phosphodiesterase and alkaline phosphatase, followed by HPLC to separate the deoxynucleosides, we showed that some of the radioactivity in the incubated DNA had been 
transferred to the $\mathrm{G}$ peak, while the control sample incubated with boiled extract contained $\left[{ }^{3} \mathrm{H}\right]$ exclusively in the $\mathrm{m}^{6} \mathrm{G}$ fraction. We concluded from this that (a) the $\mathrm{m}^{6} \mathrm{G}$ repair enzyme acts on the DNA without degrading it, and (b) the repair involves in situ demethylation (13).

Olsson and Lindahl in their assay treated calf thymus DNA with [ $\left.{ }^{3} \mathrm{H}\right] \mathrm{MNNG}$, which is known to generate $\mathrm{m}^{6} \mathrm{G}$ along with 7 -methylG $\left(\mathrm{m}^{7} \mathrm{G}\right)$ and 3-methyl $\mathrm{A}\left(\mathrm{m}^{3} \mathrm{~A}\right)$ as the major methylated base products (30). Based on the fact that $\mathrm{m}^{7} \mathrm{G}$ and $\mathrm{m}^{3} \mathrm{~A}$ residues but not $\mathrm{m}^{6} \mathrm{G}$ are readily hydrolyzed from DNA in neutral $\mathrm{pH}$, they heated and precipitated the alkylated DNA to remove most of these methylated bases prior to incubation with extracts of adapted E. coli. They followed the transfer of radioactivity to proteins by hydrolysis of these proteins to amino acids and chromatographic separation and they showed that $\left[{ }^{3} \mathrm{H}\right]-\mathrm{CH}_{3}$ was transferred exclusively to Cys residues (31). Thus they concluded that $\mathrm{m}^{6} \mathrm{G}$ repair involves enzymatic transfer of methyl groups, presumably to the repair protein itself, which Lindahl named, " $O^{6}$ -

methylguanine-DNA methyltransferase," and we subsequently gave the acronym MGMT. The Enzyme Nomenclature Commission assigned the number EC 2.1.1.63 to Ada (and all MGMTs) and the MGMT was accepted as the formal gene name by the Human Gene Map Nomenclature Committee. Several alternative names have been given to this protein, among which $\mathrm{O}^{6}$ alkylguanine transferase or AGT is also widely used (34).

Both Lindahl's group and we confirmed Cairns' prediction that the Ada protein acts stoichiometrically. Subsequently, with the discovery of mammalian MGMT, we and others confirmed the stoichiometric reaction of all MGMTs (31-34). Thus the MGMTs are not true enzymes and carry out a bimolecular reaction with a second order rate constant (32). E. coli Ada reacts at a very high rate, and human MGMT has a lower but still high rate constant of $2 \times 10^{8} \mathrm{~mol}^{-1} \mathrm{~min}^{-1}(32,34)$. Cairns speculated that, while Ada's stoichiometric reaction is wasteful because it reacts only once, it may be necessary to repair $\mathrm{m}^{6} \mathrm{G}$ rapidly in order to prevent mutagenesis due to the strongly mutagenic lesion in the replicating $E$. coli genome (23). Lindahl's studies also showed that Ada could not turn over because $S$-methylcysteine is extremely stable and there is no evidence for demethylation of methylated MGMT (28). Furthermore, $\mathrm{m}^{6} \mathrm{G}$ (and other methylated bases) in DNA could be endogenously generated by chemical reaction with S-adenosyl- L-methionine (35).

\section{Discovery of Ogt, a second MGMT in E. coli}

Our MGMT assay based on $\mathrm{m}^{6} \mathrm{G}$ demethylation is highly accurate not only because of the high specific activity of $\left[{ }^{3} \mathrm{H}\right] \mathrm{m}^{6} \mathrm{G}$ but also because quantitation of MGMT is independent of the recovery of DNA as long as the number of $\mathrm{m}^{6} \mathrm{G}$ residues present in excess in the reaction mixture is known (36). This reduced the error of quantitation of MGMT when recovery of DNA is low after incubation with a large amount of crude extract. Thus quantitation of radioactivity in $\mathrm{G}$ and $\mathrm{m}^{6} \mathrm{G}$ eluted from the same column allows calculation of the fraction of radioactivity in $\mathrm{G}$ of the total radioactivity and provides a reasonably accurate measurement of the number of MGMT molecules/cell.

We calculated that unadapted $E$. coli contained about a dozen Ada molecules/cell and the number increased to several thousand in adapted cells (36). More importantly, E. coli ada mutants also contain a similar number of Ada molecules/cell which could not be explained at the time. The situation became clear later when Margison's lab showed that $E$. coli encodes a second, constitutive MGMT gene, which they named ogt (37). Thus the residual MGMT activity in the ada mutant of the MGMT activity in unadapted $E$. coli should be partly due to Ogt. 


\section{Detection and quantitation of MGMT activity in mammalian cells}

The ubiquitous nature of MGMT was initially indicated by the presence of an Ada-like activity in B. subtilis (38). Leona Samson's laboratory cloned and characterized MGMT from the budding yeast (39-40). MGMT activity was later identified in a wide variety of organisms. Tony Pegg, in collaboration with us, identified and quantitated MGMT activity in rat liver extracts (41). Subsequent studies showed that mammalian MGMT similarly accepts the alkyl group from $O^{6}$-alkyl $\mathrm{G}$ to a Cys residue (34). The methyl acceptor Cys residue was identified after we succeeded in cloning the human and mouse MGMT cDNAs $(42,43)$.

\section{MGMT regulation in mammalian cells and its absence in Mer-/Mex- cells}

The significance of $\mathrm{m}^{6} \mathrm{G}$ as a cytotoxic lesion in mammalian genomes and the tight regulation of its repair in some tumor cells was discovered by Bernard Strauss when he showed that some mammalian lymphoma cells that are hypersensitive to MNNG (and MNU) are deficient in repair of $\mathrm{m}^{6} \mathrm{G}$; he named these $\mathrm{Mex}^{-}$(44). Rufus Day independently observed that some tumor cells are unable to reactivate MNNG-treated adenovirus and that they are deficient in $\mathrm{m}^{6} \mathrm{G}$ repair. He named these $\mathrm{Mer}^{-}$(45). We subsequently collaborated with Day and his associate, Dan Yarosh, on the quantitation of MGMT levels in various $\mathrm{Mer}^{-}$cells (33). It became evident that the $\mathrm{Mex}^{-} / \mathrm{Mer}^{-}$cells have barely detectable level of MGMT $(<200-300$ molecules/cells) compared to thousands to hundreds of thousands of MGMT molecules in various normal and tumor cells. Surprisingly, two independent clonal isolates of HeLa cells, named S3 and MR, have $\sim 10^{5}$ and $<200$ MGMT molecules/cell respectively $(46,47)$. MGMT is highly regulated, even in normal mammalian tissues (reviewed in 47).

The sensitivity of $\mathrm{Mex}^{-} / \mathrm{Mer}^{-}$cells to alkylating agents and their deficiency in $\mathrm{m}^{6} \mathrm{G}$ repair implied the cytotoxic nature of the $\mathrm{m}^{6} \mathrm{G}$ adduct in mammalian genomes, and this was investigated in great depth by many groups in more recent years $(48,49)$. We showed earlier that transgenic expression of MGMT enhances alkylation resistance of naturally MGMTdeficient Chinese hamster cells (50). These observations confirmed earlier studies correlating MGMT level and resistance to methylating agents. Furthermore, a large variation in MGMT level in various normal and tumor cells indicated its tight regulation the teleological basis of which is not clear. More importantly, the lack of MGMT in $\mathrm{Mex}^{-}$cells has profound clinical implications particularly in the treatment of glioblastoma for which the alkylating agents, including bifunctional $N$-chloroethyl- $N$-nitrosourea (CNU)-type drugs such as BCNU (carmustine) and monofunctional alkylating agents, e.g., procarbazine and temozolomide, have been extensively used (51). Although interstrand DNA crosslinks induced by CNU are the critical cytotoxic lesions, the initial adduct, $\mathrm{O}^{6}$-chloroethylG is repaired by MGMT prior to formation of the crosslink $(51,52)$. Tom Brent and others showed a correlation between MGMT levels and $\mathrm{CNU}$ resistance in various glioblastoma cells (52). While $\mathrm{m}^{6} \mathrm{G}$ generated by monofunctional alkylating agents is not as cytotoxic, its persistence in MGMT-deficient cells results in cytotoxicity following DNA replication, as Peter Karran and his colleagues initially documented (53). The concept of futile mismatch repair-replication cycle of persistent $\mathrm{m}^{6} \mathrm{G} \bullet \mathrm{T}$ pair as postulated by Karran suggests that unrepaired $\mathrm{m}^{6} \mathrm{G}$ in $\mathrm{Mex}^{-}$cells pairs with $\mathrm{T}$ during replication which then triggers the mismatch repair (MMR) process. Removal of $\mathrm{T}$ in the nascent strand is futile because of repeated incorporation of T opposite $\mathrm{m}^{6} \mathrm{G}$ during repair synthesis. The persistent nascent strand gap leading to double-strand breaks triggers signaling for apoptosis $(48,53,54)$. The resistance of MMR-deficient tumor cells to monofunctional alkylating agents provides strong evidence for the $\mathrm{m}^{6} \mathrm{G}$-initiated futile repair cycle $(55,56)$.

The molecular basis for MGMT regulation thus became an important topic for subsequent investigation. We and others showed inducibility of the MGMT gene by genotoxic agents (57). We mapped the hMGMT promoter and identified several regulatory elements including 
six putative Sp1 sites within the $\mathrm{CpG}$ island, two glucocorticoid response element (GRE), and two each of putative AP-1 and AP-2 elements (58). We investigated the potential function of each of the GRE and AP-1 sites in activation of MGMT expression $(59,60)$. Moreover, we showed that remodeling of chromatin by recruitment of the histone acetyltransferase CBP/ P300 activates the MGMT promoter (61). Several groups, including ours, explored the basis of MGMT extinction in $\mathrm{Mer}^{-} / \mathrm{Mex}^{-}$cells. The role of $\mathrm{CpG}$ methylation was indicated by the observed conversion of $\mathrm{Mex}^{-}$into $\mathrm{Mex}^{+}$cells after treatment with $\mathrm{CpG}$ demethylating agent 5-azacytidine (62). However, the total repression of MGMT in $\mathrm{Mex}^{-}$cells appears to be due to extensive methylation of $\mathrm{CpG}$ in both the promoter and the transcribed sequences of the MGMT gene, which is unusually large (> $180 \mathrm{~kb}$; ref. 63) relative to the small size( $\sim 1 \mathrm{~kb})$ of the mRNA $(64,65)$.

\section{Cloning of mammalian MGMT cDNA}

Our and others' initial efforts in cloning the MGMT gene by genomic complementation were uniformly unsuccessful, presumably because of the enormous size of the MGMT gene, as became evident later. On the other hand, cross-species phenotypic complementation turned out to be a powerful tool for cloning DNA repair genes in the form of cDNA. We predicted success in this strategy, at least for MGMT, because of the similarity of biochemical properties of $E$. coli Ada and partially purified mammalian MGMTs (32).

We succeeded in cloning the human MGMT cDNA using a phenotypic complementation assay by transforming MGMT-negative ( $a d a$, ogt) E. coli with a human cDNA library and screening for MNNG-resistant clones. We isolated several such clones and confirmed that the resistance was conferred due to expression of MGMT encoded by the plasmid (42). Sekiguchi, Karran and their collaborators subsequently cloned mammalian MGMT cDNAs using more conventional approaches $(66,67)$. Purification of the recombinant human MGMT allowed us to identify the methylacceptor Cys residue and also to clone the mouse MGMT cDNA and purify the polypeptide. As expected, the human and mouse MGMT have extensive sequence identity and complete conservation of the sequence PCHRV which includes the alkylacceptor Cys 145 residue in the human MGMT (and Cys149 in the mouse protein). This sequence is conserved in all other MGMTs including Ada (47). The mammalian MGMT is much smaller than the Ada protein which contains the $\mathrm{N}$-terminal extension that folds into a distinct domain connected by a hinge sequence with the C-terminal MGMT domain (28). Samson's group published the cloning of the yeast MGMT gene using the same strategy a little earlier than when we cloned the human MGMT cDNA (39). We extended the cross species phenotypic complementation strategy to subsequently clone the cDNA of the human AlkA homolog which we named N-methylpurine-DNA glycosylase (MPG; 68); Samson's group independently named it 3-alkyladenine-DNA glycosylase (AAG).

\section{Discovery of $0^{6}$-benzyl G as an MGMT pseudosubstrate}

Early studies suggested that requirement of the presence of $\mathrm{m}^{6} \mathrm{G}$ in an oligonucleotide to serve as the MGMT substrate. Pegg and Moschel discovered that $\mathrm{O}^{6}$-benzylG $\left(\mathrm{B}^{6} \mathrm{G}\right)$ is a potent inhibitor of MGMT because of its high affinity and ability to function as a pseudosubstrate (69). This was a seminal discovery with significant clinical implications because $\mathrm{B}^{6} \mathrm{G}$ treatment sensitizes tumor cells and xenografts to BCNU $(70,71)$. More recent studies of the biological effects of $B^{6} \mathrm{G}$ and of structural studies of MGMT to examine its binding to $\mathrm{B}^{6} \mathrm{G}$, are described in detail elsewhere in this volume.

\section{Future Directions}

Although the pace of research on MGMT might have slowed down somewhat in recent years, there are still many unanswered questions about regulation and fate of the methylated protein, 
and also the possibility of additional repair-unrelated functions of this unusual protein. These should keep the investigators busy for some years to come. The translational aspect of MGMT, namely its tumor-cell specific inhibition with $\mathrm{B}^{6} \mathrm{G}$ or some other small molecules for drug sensitization of tumors, along with ectopic MGMT-mediated protection of healthy tissues from drug toxicity, should also remain a challenging topic.

\section{Acknowledgments}

The MGMT studies in my laboratory were initiated in 1978 in collaboration with Bimal C. Pal and Robert S. Foote who are organic chemists. These evolved into investigations in areas of cell biology which were far beyond the range of my own expertise. This progression of scientific endeavor could not have been possible without collaboration of so many other colleagues including Warren Masker, Tony Pegg, Rufus Day, Dan Yarosh, Bernd Kaina, Tom Brent, Mituo Ikenaga, and many talented postdocs and students in my own lab. My research efforts were supported by USPHS grants R01 CA31721, R01 ES07572 and R01 CA53791.

\section{References}

1. Aas PA, Otterlei M, Falnes PO, Vagbo CB, Skorpen F, Akbari M, Sundheim O, Bjoras M, Slupphaug G, Seeberg E, Krokan HE. Human and bacterial oxidative demethylases repair alkylation damage in both RNA and DNA. Nature 2002;421:859-863. [PubMed: 12594517]

2. Trewick SC, Henshaw TF, Hausinger RP, Lindahl T, Sedgwick B. Oxidative demethylation by Escherichia coli AlkB directly reverts DNA base damage. Nature 2002;419:174-178. [PubMed: 12226667]

3. Sedgwick B, Bates PA, Paik J, Jacobs SC, Lindahl T. Repair of alkylated DNA: Recent advances. DNA Repair (Amst). 2006

4. Miller EC, Miller JA. The metabolism of chemical carcinogens to reactive electrophiles and their possible mechanisms of action in carcinogenesis in chemical carcinogens (ed. C. E. Searle). ACS Monograph 1996;173:737-762.

5. Lawley, PD. Carcinogenesis by alkylating agents. In: Searle, CE., editor. Chemical Carcinogens. American Chemical Society: Washington, DC; 1984. p. 83-244.

6. Brookes P, Lawley PD. The reaction of mustard gas with nucleic acids in vitro and in vivo. Biochem J 1960;77:478-484. [PubMed: 16748853]

7. Magee PN. The experimental basis for the role of nitroso compounds in human cancer. Cancer Surv 1989;8:207-239. [PubMed: 2696578]

8. Singer, B.; Grunberger, D. Molecular Biology of Mutagens and Carcinogens: Intrinsic Properties of Nucleic Acids. Plenum Press: New York; 1983. p. 15-44.

9. Loveless A. Possible relevance of O-6 alkylation of deoxyguanosine to the mutagenicity and carcinogenicity of nitrosamines and nitrosamides. Nature 1969;223:206-207. [PubMed: 5791738]

10. Goth R, Rajewsky MF. Persistence of $\mathrm{O}^{6}$-ethylguanine in rat-brain DNA: correlation with nervous system-specific carcinogenesis by ethylnitrosourea. Proc Natl Acad Sci USA 1974;71:639-643. [PubMed: 4522778]

11. Kleihues P, Margison GP. Carcinogenicity of N-methyl-N-nitrosourea: possible role of excision repair of O6-methylguanine from DNA. J Natl Cancer Inst 1974;53:1839-1841. [PubMed: 4436874]

12. Abbott PJ, Saffhill R. DNA synthesis with methylated poly $(\mathrm{dC}-\mathrm{dG})$ templates. Evidence for a competitive nature to miscoding by $\mathrm{O}^{6}$-methylguanine. Biochim Biophys Acta 1979;562:51-61. [PubMed: 373805]

13. Foote RS, Mitra S, Pal BC. Demethylation of $\mathrm{O}^{6}$-methylguanine in a synthetic DNA polymer by an inducible activity in Escherichia coli. Biochem Biophys Res Commun 1980;97:654-659. [PubMed: 7008792]

14. Dodson LA, Foote RS, Mitra S, Masker WE. Mutagenesis of bacteriophage T7 in vitro by incorporation of O6-methylguanine during DNA synthesis. Proc Natl Acad Sci USA 1982;79:74407444. [PubMed: 6961422]

15. Loechler EL, Green CL, Essigmann JM. In vivo mutagenesis by O6-methylguanine built into a unique site in a viral genome. Proc Natl Acad Sci USA 1984;81:6271-6275. [PubMed: 6093094] 
16. Snow ET, Foote RS, Mitra S. Base-pairing properties of O6-methylguanine in template DNA during in vitro DNA replication. J Biol Chem 1984;259:8095-8100. [PubMed: 6376499]

17. Snow ET, Foote RS, Mitra S. Kinetics of incorporation of O6-methyldeoxyguanosine monophosphate during in vitro DNA synthesis. Biochem 1984;23:4289-4294. [PubMed: 6386047]

18. Reha-Krantz LJ, Nonay RL, Day RS, Wilson SH. Replication of O6-methylguanine-containing DNA by repair and replicative DNA polymerases. J Biol Chem 1996;271:20088-20095. [PubMed: 8702729]

19. Vojtechovsky J, Eaton MD, Gaffney B, Jones R, Berman HM. Structure of a new crystal form of a DNA dodecamer containing T. $\left(\mathrm{O}^{6} \mathrm{Me}\right) \mathrm{G}$ base pairs. Biochem 1995;34:16632-16640. [PubMed: 8527436]

20. Patel DJ, Shapiro L, Kozlowski SA, Gaffney BL, Jones RA. Structural studies of the O6meG.T interaction in the d(C-G-T-G-A-A-T-T-C-O6meG-C-G) duplex. Biochemistry 1986;25:1036-1042. [PubMed: 3964659]

21. Samson L, Cairns J. A new pathway for DNA repair in Escherichia coli. Nature 1977;267:281-283. [PubMed: 325420]

22. Friederg, EC.; Walker, GC.; Siede, W.; Wood, RD.; Schultz, RA.; Ellenberger, T. DNA Repair and Mutagenesis. Vol. 2. ASM Press: 2005.

23. Cairns J, Robins P, Sedgwick B, Talmad P. The inducible repair of alkylated DNA. Prog Nucl Acids Res Mol Biol 1981;26:237-244.

24. Volkert MR. Adaptive response of Escherichia coli to alkylation damage. Environ Mol Mutagen 1988;11:241-255. [PubMed: 3278898]

25. Nakamura T, Tokumoto Y, Sakumi K, Koike G, Nakabeppu Y, Sekiguchi M. Expression of the ada gene of Escherichia coli in response to alkylating agents. Identification of transcriptional regulatory elements. J Mol Biol 1988;202:483-494. [PubMed: 3139888]

26. Sakumi K, Sekiguchi M. Regulation of expression of the ada gene controlling the adaptive response. Interactions with the ada promoter of the Ada protein and RNA polymerase. J Mol Biol 1989;205:373-385. [PubMed: 2648001]

27. Shevell DE, Walker GC. A region of the Ada DNA-repair protein required for the activation of ada transcription is not necessary for activation of alkA. Proc Natl Acad Sci USA 1991;88:9001-9005. [PubMed: 1924363]

28. Lindahl T, Sedgwick B, Sekiguchi M, Nakabeppu Y. Regulation and expression of the adaptive response to alkylating agents. Annu Rev Biochem 1988;57:133-157. [PubMed: 3052269]

29. Rohankhedkar MS, Mulrooney SB, Wedemeyer WJ, Hausinger RP. The AidB component of the Escherichia coli adaptive response to alkylating agents is a flavin-containing, DNA-binding protein. J Bacteriol 2006;188:223-230. [PubMed: 16352838]

30. Olsson M, Lindahl T. Repair of alkylated DNA in Escherichia coli. Methyl group transfer from $\mathrm{O}^{6}$. methylguanine to a protein cysteine residue. J Biol Chem 1980;255:10569-10571. [PubMed: 7000780]

31. Demple B, Sedgwick B, Robins P, Totty N, Waterfield MD, Lindahl T. Active site and complete sequence of the suicidal methyltransferase that counters alkylation mutagenesis. Proc Natl Acad Sci USA 1985;82:2688-2692. [PubMed: 3887409]

32. Bhattacharyya D, Foote R, Boulden A, Mitra S. Physicochemical studies of human $\mathrm{O}^{6}$ methylguanine-DNA Methyltransferase. Eur J Biochem 1990;193:337-343. [PubMed: 2226457]

33. Yarosh DB, Foote RS, Mitra S, Day RS 3rd. Repair of O6-methylguanine in DNA by demethylation is lacking in Mer- human tumor cell strains. Carcinogenesis 1983;4:199-205. [PubMed: 6825208]

34. Pegg AE, Dolan ME, Moschel RC. Structure, function, and inhibition of $\mathrm{O}^{6}$-alkylguanine-DNA alkyltransferase. Prog Nucleic Acid Res Mol Biol 1995;51:167-223. [PubMed: 7659775]

35. Rydberg B, Lindahl T. Nonenzymatic methylation of DNA by the intracellular methyl group donor S-adenosyl-L-methionine is a potentially mutagenic reaction. EMBO J 1982;1:211-216. [PubMed: 7188181]

36. Mitra S, Pal BC, Foote RS. $\mathrm{O}^{6}$-methylguanine-DNA methyltransferase in wild-type and ada mutants of Escherichia coli. J Bacteriol 1982;152:534-537. [PubMed: 6749819] 
37. Potter PM, Wilkinson MC, Fitton J, Carr FJ, Brennand J, Cooper DP, Margison GP. Characterisation and nucleotide sequence of ogt, the $\mathrm{O}^{6}$-alkylguanine-DNA-alkyltransferase gene of E. coli, Nucleic Acids Res 1987;15:9177-9193. [PubMed: 2825131]

38. Hadden CT, Foote RS, Mitra S. Adaptive response of Bacillus subtilis to N-methyl-N'-nitro-Nnitrosoguanidine. J Bacteriol 1983;153:756-762. [PubMed: 6401705]

39. Xiao W, Derfler B, Chen J, Samson L. Primary sequence and biological functions of a Saccharomyces cerevisiae O6-methylguanine/O4-methylthymine DNA repair methyltransferase gene. EMBO J 1991;10:2179-2186. [PubMed: 2065659]

40. Sassanfar M, Dosanjh MK, Essigmann JM, Samson L. Relative efficiencies of the bacterial, yeast, and human DNA methyltransferases for the repair of O6-methylguanine and O4-methylthymine. Suggestive evidence for O4-methylthymine repair by eukaryotic methyltransferases. J Biol Chem 1991;266:2767-2771. [PubMed: 1993655]

41. Pegg AE, Wiest L, Foote RS, Mitra S, Perry W. Purification and properties of $\mathrm{O}^{6}$-methylguanineDNA transmethylase from rat liver. J Biol Chem 1983;258:2327-2333. [PubMed: 6822564]

42. Tano K, Shiota S, Collier J, Foote RS, Mitra S. Isolation and structural characterization of a cDNA clone encoding the human DNA repair protein for $\mathrm{O}^{6}$-alkylguanine. Proc Natl Acad Sci USA 1990;87:686-690. [PubMed: 2405387]

43. Shiota S, von Wronski MA, Tano K, Bigner DD, Brent TP, Mitra S. Characterization of cDNA encoding mouse DNA repair protein $\mathrm{O}^{6}$-methylguanine-DNA methyltransferase and high-level expression of the wild-type and mutant proteins in E. coli. Biochem 1992;31:1897-1903. [PubMed: 1371399]

44. Sklar R, Strauss RB. Removal of O6-methylguanine from DNA of normal and xeroderma pigmentosum-derived lymphoblastoid lines. Nature 1981;289:417-420. [PubMed: 7464910]

45. Day RS 3rd, Ziolkowski CH, Scudiero DA, Meyer SA, Lubiniecki AS, Girardi AJ, Galloway SM, Bynum GD. Defective repair of alkylated DNA by human tumour and SV40-transformed human cell strains. Nature 1980;288:724-727. [PubMed: 6256643]

46. Yarosh DB, Rice M, Day RS 3rd, Foote RS, Mitra S. O6-Methylguanine-DNA methyltransferase in human cells. Mutat Res 1984;131:27-36. [PubMed: 6694657]

47. Mitra S, Kaina B. Regulation of repair of alkylation damage in mammalian genomes. Prog Nucl Acids Res Mol Biol 1993;44:109-141.

48. Ochs K, Kaina B. Apoptosis induced by DNA damage O6-methylguanine is Bcl-2 and caspase-9/3 regulated and Fas/caspase-8 independent. Cancer Res 2000;60:5815-5824. [PubMed: 11059778]

49. Hickman MJ, Samson LD. Apoptotic signaling in response to a single type of DNA lesion, O(6)methylguanine. Mol Cell 2004;14:105-116. [PubMed: 15068807]

50. Kaina B, Fritz G, Mitra S, Coquerelle T. Transfection and expression of human O6-methylguanineDNA methyltransferase (MGMT) cDNA in Chinese hamster cells: the role of MGMT in protection against the genotoxic effects of alkylating agents. Carcinogenesis 1991;12:1857-1867. [PubMed: 1657427]

51. Ludlum DB. DNA alkylation by the haloethylnitrosoureas: Nature of modifications produced and their enzymatic repair or removal. Mutat Res 1990;233:117-126. [PubMed: 2233793]

52. Brent TP, Houghton JA, Houghton PJ. $\mathrm{O}^{6}$-alkylguanine-DNA alkyltransferase activity correlates with the therapeutic response of human rhabdomyosarcoma xenografts to 1-(2-chlorethyl)-3(trans-4-methylcyclohexyl)-1-nitrosourea. Proc Natl Acad Sci USA 1985;82:2985-2989. [PubMed: 3857628]

53. Karran P, Hampson RR. Genomic instability and tolerance to alkylating agents. Cancer Surv 1996;28:69-85. [PubMed: 8977029]

54. Roos WP, Kaina B. DNA damage-induced cell death by apoptosis. Trends Mol Med 2006;12:440 450. [PubMed: 16899408]

55. Pepponi R, Marra G, Fuggetta MP, Falcinelli S, Pagani E, Bonmassar E, Jiricny J, D’Atri S. The effect of O6-alkylguanine-DNA alkyltransferase and mismatch repair activities on the sensitivity of human melanoma cells to temozolomide, 1,3-bis(2-chloroethyl)1-nitrosourea, and cisplatin. J Pharmacol Exp Ther 2003;304:661-668. [PubMed: 12538819] 
56. Barvaux VA, Ranson M, Brown R, McElhinney RS, McMurry TB, Margison GP. Dual repair modulation reverses Temozolomide resistance in vitro. Mol Cancer Ther 2004;3:123-127. [PubMed: 14985452]

57. Fritz G, Tano K, Mitra S, Kaina B. Inducibility of the DNA repair gene encoding O6-methylguanineDNA methyltransferase in mammalian cells by DNA-damaging treatments. Mol Cell Biol 1991;11:4660-4668. [PubMed: 1875945]

58. Harris LC, Potter PM, Tano K, Shiota S, Mitra S, Brent TP. Characterization of the promoter region of the human O6-methylguanine-DNA methyltransferase gene. Nucleic Acids Res 1991;19:61636167. [PubMed: 1956775]

59. Biswas T, Ramana CV, Srinivasan G, Boldogh I, Hazra TK, Chen Z, Tano K, Thompson EB, Mitra S. Activation of human O6-methylguanine-DNA methyltransferase gene by glucocorticoid hormone. Oncogene 1999;18:525-532. [PubMed: 9927209]

60. Boldogh I, Ramana CV, Chen Z, Biswas T, Hazra TK, Grosch S, Grombacher T, Mitra S, Kaina B. Regulation of expression of the DNA repair gene O6-methylguanine-DNA methyltransferase via protein kinase C-mediated signaling. Cancer Res 1998;58:3950-3956. [PubMed: 9731508]

61. Bhakat KK, Mitra S. Regulation of the human $\mathrm{O}^{6}$-methylguanine-DNA methyltransferase gene by transcriptional coactivators cAMP response element-binding protein-binding protein and $\mathrm{p} 300$. J Biol Chem 2000;275:34197-34204. [PubMed: 10942771]

62. von Wronski MA, Brent TP. Effect of 5-azacytidine on expression of the human DNA repair enzyme O6-methylguanine-DNA methyltransferase. Carcinogenesis 1994;15:577-582. [PubMed: 7511991]

63. Iwakuma T, Shiraishi A, Fukuhara M, Kawate H, Sekiguchi M. Organization and expression of the mouse gene for DNA repair methyltransferase. DNA Cell Biol 1996;15:863-872. [PubMed: 8892758]

64. Bhakat KK, Mitra S. CpG methylation-dependent repression of the human O6-methylguanine-DNA methyltransferase gene linked to chromatin structure alteration. Carcinogenesis 2003;24:1337-1345. [PubMed: 12807730]

65. Costello JF, Futscher BW, Tano K, Graunke DM, Pieper RO. Graded methylation in the promoter and body of the O6-methylguanine DNA methyltransferase (MGMT) gene correlates with MGMT expression in human glioma cells. J Biol Chem 1994;269:17228-17237. [PubMed: 8006031]

66. Rydberg B, Spurr N, Karran P. cDNA cloning and chromosomal assignment of the human O6methylguanine-DNA methyltransferase. cDNA expression in Escherichia coli and gene expression in human cells. J Biol Chem 1990;265:9563-9569. [PubMed: 2188979]

67. Hayakawa H, Koike G, Sekiguchi M. Expression and cloning of complementary DNA for a human enzyme that repairs O6-methylguanine in DNA. J Mol Biol 1990;213:739-747. [PubMed: 2359121]

68. Chakravarti D, Ibeanu GC, Tano K, Mitra S. Cloning and expression in Escherichia coli of a human cDNA encoding the DNA repair protein N-methylpurine-DNA glycosylase. J Biol Chem 1991;266:15710-15715. [PubMed: 1874728]

69. Dolan ME, Moschel RC, Pegg AE. Depletion of mammalian O6-alkylguanine-DNA alkyltransferase activity by O6-benzylguanine provides a means to evaluate the role of this protein in protection against carcinogenic and therapeutic alkylating agents. Proc Natl Acad Sci USA 1990;87:5368-5372. [PubMed: 2164681]

70. Schold SC Jr, Kokkinakis DM, Rudy JL, Moschel RC, Pegg AE. Treatment of human brain tumor xenografts with O6-benzyl-2'-deoxyguanosine and BCNU. Cancer Res 1996;56:2076-2081. [PubMed: 8616853]

71. Chen JM, Zhang YP, Moschel RC, Ikenaga M. Depletion of O6-methylguanine-DNA methyltransferase and potentiation of 1,3-bis(2-chloroethyl)-1-nitrosourea antitumor activity by O6benzylguanine in vitro. Carcinogenesis 1993;14:1057-1060. [PubMed: 8504466] 

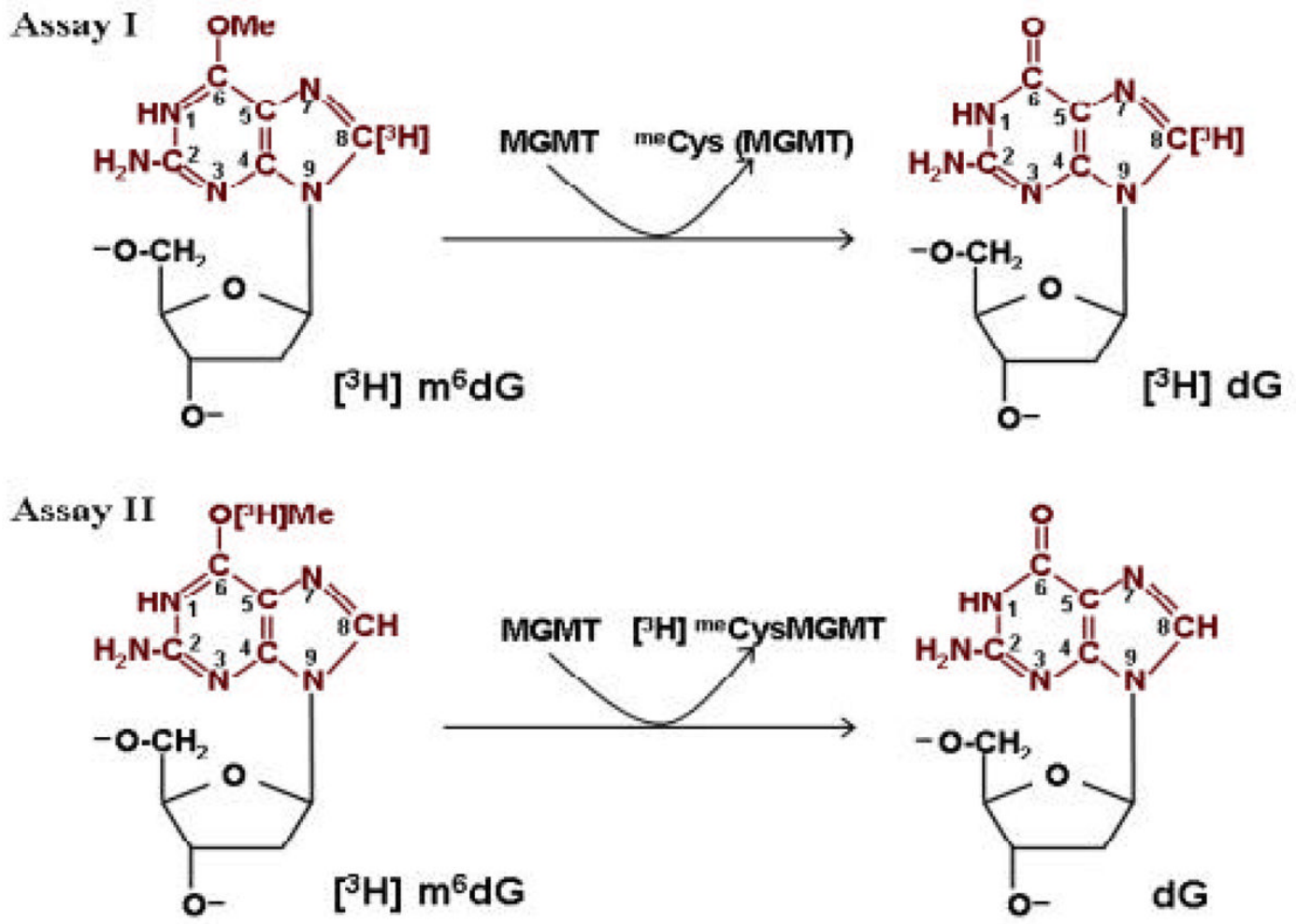

Fig. 1. MGMT Assay

Two complementary quantitative assays for MGMT were developed using $\left[{ }^{3} \mathrm{H}\right]$-labeled $\mathrm{m}^{6} \mathrm{G}-$ containing DNA substrates. (Only the $\mathrm{O}^{6}$-methyldeoxyguanosine moiety is shown here for convenience.) In (I), a synthetic oligodeoxynucleotide containing $\mathrm{m}^{6} \mathrm{G}$ labeled with $\left[{ }^{3} \mathrm{H}\right]$ at $\mathrm{C}-8$ is used as the substrate. Demethylation of $\mathrm{m}^{6} \mathrm{G}$ by MGMT generates $\left[{ }^{3} \mathrm{H}\right] \mathrm{G}$ which is then separated from $\left[{ }^{3} \mathrm{H}\right] \mathrm{m}^{6} \mathrm{G}$ by HPLC. The amount of MGMT equals that of $\left[{ }^{3} \mathrm{H}\right] \mathrm{G}$. In (II), DNA methylated with a $\left[{ }^{3} \mathrm{H}\right]$ methylating agent is used as the substrate. MGMT is radiolabeled at the methyl-acceptor Cys during the methyltransferase reaction. After hydrolysis, $\left[{ }^{3} \mathrm{H}\right]$ methylCys is quantitated. 